\title{
Wind Energy Usage for Building Heating Applying Hydraulic System
}

\section{Tadas Ždankus*, Jurgita Černeckienè, Leonas Greičius, Vidas Stanevičius, Nerijus Bunikis}

Kaunas University of Technology, Faculty of Civil Engineering and Architecture, Studentu st. 48, LT-51367 Kaunas, Lithuania

*Corresponding author: tadas.zdankus@ktu.lt

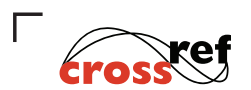

http://dx.doi.org/10.5755/j01.sace.25.2.21542
The most ordinary way to use wind energy for building heating needs is to convert mechanical wind energy into electrical energy and to use electrical energy for heating. Though there are ways to convert mechanical wind energy into thermal energy without transitional energy conversion - hydraulic systems can be implemented for this purpose. Wind rotor gives rotational motion to the pump of hydraulic system and it creates fluid circulation in the hydraulic system. A part of liquid mechanical energy due to hydraulic resistance of the system converts into the thermal energy when the liquid circulates in the close hydraulic loop and it heats up the liquid that can be used for heating purposes. Different hydraulic valves can be integrated in the hydraulic system and they can work as the load-regulating component of the system. The purpose of the study was to adjust the hydraulic load to the optimal value in order to generate a maximum amount of thermal energy.

During the study, the work of a wind rotor was simulated by an electric motor, rotated at different frequencies (without feedback). The hydraulic system consisted of a gear pump, an adjustable load regulation valve, pipes, oil tank, sensors for measuring motor shaft rotational speed, oil temperature and pressure. The experiments were carried out at different electromotor speeds: 12.5, 17.5 and 22.5 $\mathrm{Hz}$, and for different oil temperatures in the range of 20 to $50{ }^{\circ} \mathrm{C}$. The relationship between the opening degree of the valve and the amount of generated thermal energy was determined. The study showed that wind energy usage can cover a significant part of the building's thermal energy needs at the same time reducing pollution and the usage of the fossil fuel for heating purposes.

Keywords: energy conversion, heating of the building, heat production, hydraulic system, wind energy.

In recent years, the questions on the usage of the sustainable and renewable energy resources are being solved considering various aspects. Where earlier only the engineers or ecologists have solved the objectives related to this topic, then lately, we can hear more and more involvement of the politicians, sociologists and economists in this field (Stigka et al. 2014). Such questions are directly related to the problem of the climate warming, and the dominant feeling in the world shall condition determining the higher goals that would help managing or even stopping the climate changes. Many factors have conditioned the leap forward in the field of the renewable energy resources - beginning from the decrease of the fossil fuels, increase the global energy needs, the aim to decrease the impact of the greenhouse effect on the ecological situation of the planet (Katinas et al. 2014), etc. For the separate countries having not enough fossil fuels renewable energy usage is very important because of the economical wealth of the country and even sovereignty (Katinas et al. 2014).
JSACE 2/25

Wind Energy Usage for Building Heating Applying Hydraulic System

Received 2018/08/30

Accepted after revision 2018/12/03

\section{Introduction}

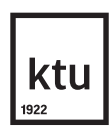

Journal of Sustainable Architecture and Civil Engineering Vol. 2 / No. 25 / 2019 pp. $63-70$ DOI 10.5755/j01.sace.25.2.21542 
One of the renewable energy resources that usage possibilities are analyzed further in this article is the mechanical wind energy. In its widest sense the primary source of the wind energy is the sun, but in the interest of clarity, it is necessary to say that there is a tradition to exclude between the direct usage of the sun radiation energy and energy forms emerged due to the sun radiation.

Wind energy usage for heating purposes is interesting as the study object because the changes of the demand for the heat energy for building heating during the year (Černeckiene, 2015) is close to the distribution of the wind potential (according to the Lithuanian climatology data). In addition, when the energy is used at the time of its production or in the near future, the question of the energy storage shall become less relevant. The system of wind energy usage (Fig. 1) consists of a few analysis objects and units, such as conditions of the climatology area, design of the wind rotor, energy conversion and transformation system (EC and ET), energy transfer system, system for storage of the excessive energy and for assurance of the sufficient energy amount (EA). All such constituent parts shall make impact to the common energy efficiency and economic attractiveness. At the same time the need for the cooperation of the professionals from various areas shall arise in the process for implementation of the renewable energy resources, because it includes the climatology, mechanics (aerodynamics, substance resistance, thermodynamics) and in case of the electricity production - electrical engineering.

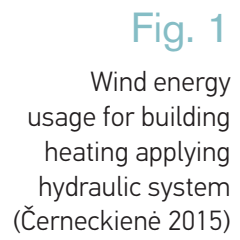

Fig. 1

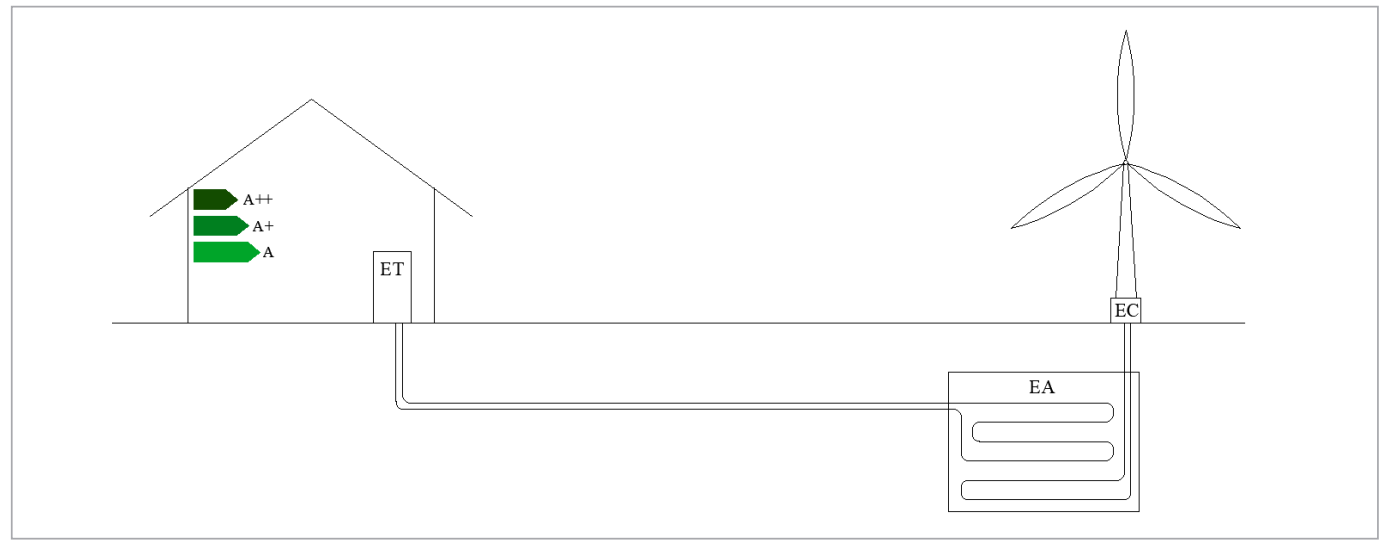

When the fluid flows through various valves or throttles increase of the fluid temperature is often observed in the hydraulic drives (Žiedelis 2009). In the energetics before the operating of the water or steam boiler, the water supply pump is turned on and the water circulates in the closed circle. An increase of water temperature by few degrees can be noticed due to the recirculation during the short interval. In both mentioned cases, a part of the mechanical energy of the fluid flow converted into the heat due to the friction and local hydraulic losses (Robert et al. 1996, Yeaple 1995). If the heat does not transfer into the environment, fluid temperature increases, what demonstrate the possibility to generate the heat using the hydraulic system. When the energy source of the hydraulic system, driving the hydraulic pump, is the electromotor or the internal-combustion engine, in such case it is not purposeful to generate the heat by the hydraulic system and use it for heating of the building. It is simpler and more efficient use the electric heating units and burn the fuel in the boilers. However, if the energy source of the hydraulic system is the wind got free, the situation will change drastically. The investments to such system can be little, there is a lot of experience in the field of the systems of the electricity generation from wind, and big efficiency of such system, as the heat generator, is possible at that moment (Černeckiene and Ždankus 2015, Ždankus et al. 2016). Namely, the hydraulic system, as the heat generator, that pump would be rotated by the movement transferred from the wind rotor, is the object of the experimental studies 
discussed in this article. Possibilities of the hydraulic system characterized as non-complex, collected from the simple elements were investigated experimentally, and the optimum work modes in case of different values of the wind velocity, as well as the possibilities to automatize the system work have been determined.

The experimental device was designed for simulating and investigating the operation of the hydraulic system driven the wind. The rotational motion of the wind rotor transformed by the reduction gear was simulated by electromotor. Three-phase asynchronous, four pole electromotor with the power of $1.5 \mathrm{~kW}\left(\mathrm{BEVI}-4 \mathrm{AK} 290 \mathrm{~L}-4 \mathrm{~B} 14, \cos \varphi=0.77, \eta_{\text {motor }}=0.828\right)$ was used in experimental set-up. The fixed rotation frequency of electromotor $\left(n_{\text {set }}\right)$ meant the simulated rotation frequency of wind rotor for certain wind speed. The fixed $n_{\text {set }}$ values correspond to the wind speed between $3.92 \mathrm{~m} / \mathrm{s}$ and $5.06 \mathrm{~m} / \mathrm{s}$ taking into account that the wind is harvested with the efficiency 0.45 by the wind rotor with $10 \mathrm{~m}^{2}$ area when the air density is $1.293 \mathrm{~kg} / \mathrm{m}^{3}$ (Ždankus et al, 2016). The electromotor was calibrated in the special laboratory before starting the experimental investigation. The detailed data of calibration and methodology of computation of the simulated wind speed can be found in our previous study (Ždankus et al., 2016). Electromotor was mounted by the cover of the oil tank, and its shaft was connected by the rigid coupling to the shaft of the pump of the hydraulic system. Hydraulic system assembled of the oil tank, hydraulic pump, supply (pressure) pipe, flow (load) control valve, heat exchanger, and return pipe (Fig. 2). Hydraulic system contained $20 \mathrm{l}$ of oil (ISO viscosity degree $32, \rho_{\text {oil_20 }} 0^{\circ}=867 \mathrm{~kg} / \mathrm{m}^{3}, v_{\text {oil_20 }} 0^{\circ}=65 \cdot 10^{-6} \mathrm{~m}^{2} / \mathrm{s}, \mathrm{c}=1.67 \mathrm{~kJ} /(\mathrm{kg} \cdot \mathrm{K})$ ). The hydraulic gear pump Vivolo-X2P5702 $\left(V_{\text {pump }}=26.2 \mathrm{~cm}^{3} /\right.$ rot.) was used during investigation. The hydraulic pump was fully submerged into the oil in the rectangle steel oil tank. Internal diameter of all pipes was $d=20 \mathrm{~mm}$. Oil tank, pipes, valve and the heat exchanger were covered by the layer of the heat insulation material (polystyrene foam), in order to minimize the heat losses to the environment.

Rotation frequency of the shaft of the electromotor was changed by the electric frequency converter Mitsubishi Electric (FR-D740036SC-EC, three-phase, $1.5 \mathrm{~kW}, 0.2 \ldots .400 \mathrm{~Hz}$ ). The real rotation frequency of the shaft of the electromotor $n$ was measured by the tachometer Testo 465 (tolerance: $0.01 \mathrm{rpm}$ ).

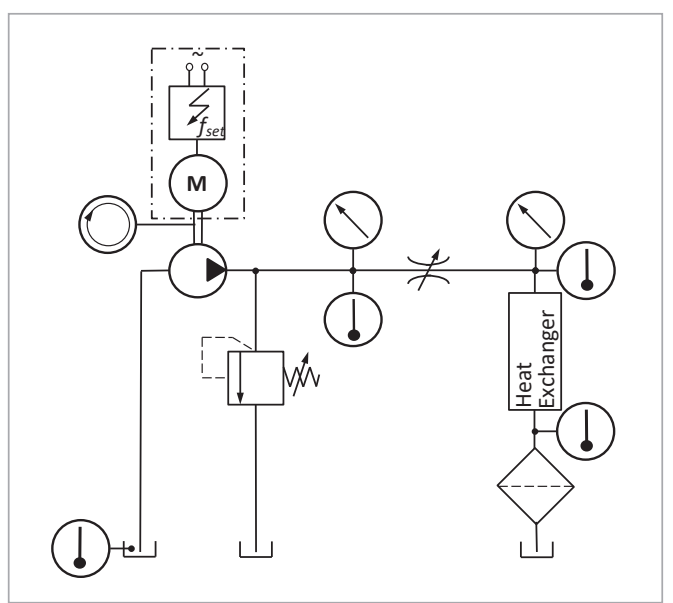

Load of the hydraulic system - resistance to the flow was changed by decreasing or increasing the permeability of the flow control valve - loading valve. The loss of the liquid mechanical energy in the loading valve showed the potential of the system to generate the heat. Valve opening position was changed by the revolutions from the fully opened position $a_{\max }=9$ revolutions up to the fully closed position $a=0$ revolutions. The opening degree of the loading valve was calculated by formula: $y=a / a_{\max }$.

Pressure before the loading valve was measured by the pressure sensor NAH 25.0 A $(0 \div 25$ bar, $4 \div 20 \mathrm{~mA}$, measurement precision $0.3 \%$ ), behind the valve - by the pressure sensor NAH $2.5 \mathrm{~A}$ $(0 \div 2.5$ bar, $4 \div 20 \mathrm{~mA}, 0.3 \%)$. During the experimental investigation the difference of the pressure before $\left(p_{1}\right)$ and behind $\left(p_{2}\right)$ the loading valve was calculated: $\Delta p=p_{1}-p_{2}$. It was assumed that liquid mechanical energy loss in the loading valve was equal to generated heat in the valve. Thermal energy of generated heat was calculated by the formula:

\section{Methods}

Fig. 2

Scheme of the experimental setup (Ždankus et al. 2016) 


$$
P_{l}=\Delta p Q=\Delta p n V_{\text {pump }}
$$

During the experimental investigation, the oil temperature was measured in 4 points: in the oil tank, before the loading valve, before the heat exchanger and behind the heat exchanger. In order to measure the temperature, the thermos-sensors were used (TJ4-Pt100, precision class 1/3B). Indications of the thermos-sensors were read and transferred to the computer by the data storage device Data Logger PT-104.

In order to check the reproducibility and reliability of the results of the experimental investigation, the statistical parameters were calculated for every test series, performed at the same conditions. It was determined that the results of the experimental investigation were quite precise, reliable and reproducible.

\section{Results}

The experiments were carried out at rotation speeds of the shaft of the electromotor: $n_{\text {set }}=12.5$, 17.5 and $22.5 \mathrm{~Hz}$. The previous studies are already made with the $n_{\text {set }}=10.0,15.0,20.0$ and $25.0 \mathrm{~Hz}$, so this study expands the database and increases the accuracy of the experimental investigation. In one case the experimental series were started from the fully opened loading valve $\gamma=1$. It was the minimum load of the hydraulic system. Next the valve has been fluently closing until $y=0.11$. In other case the series started from almost closed $(y=0.11)$ loading valve and the opening degree of the valve was changed from $\gamma=0.11$ to fully opened position $\gamma=1$. Undistinguished different of the amount of generated thermal energy was noticed.

Dependence of the amount of thermal energy $\left(P_{l}\right)$ generated while liquid passed the valve on the opening degree $(\gamma)$ of the loading valve is shown in Fig. 3.

Fig. 3

Dependence of the amount of generated thermal

energy on the opening degree of the loading valve

for $n_{\text {set }}=12.5$,

17.5 and $22.5 \mathrm{~Hz}$ at $\mathrm{T} \approx 20^{\circ} \mathrm{C}$

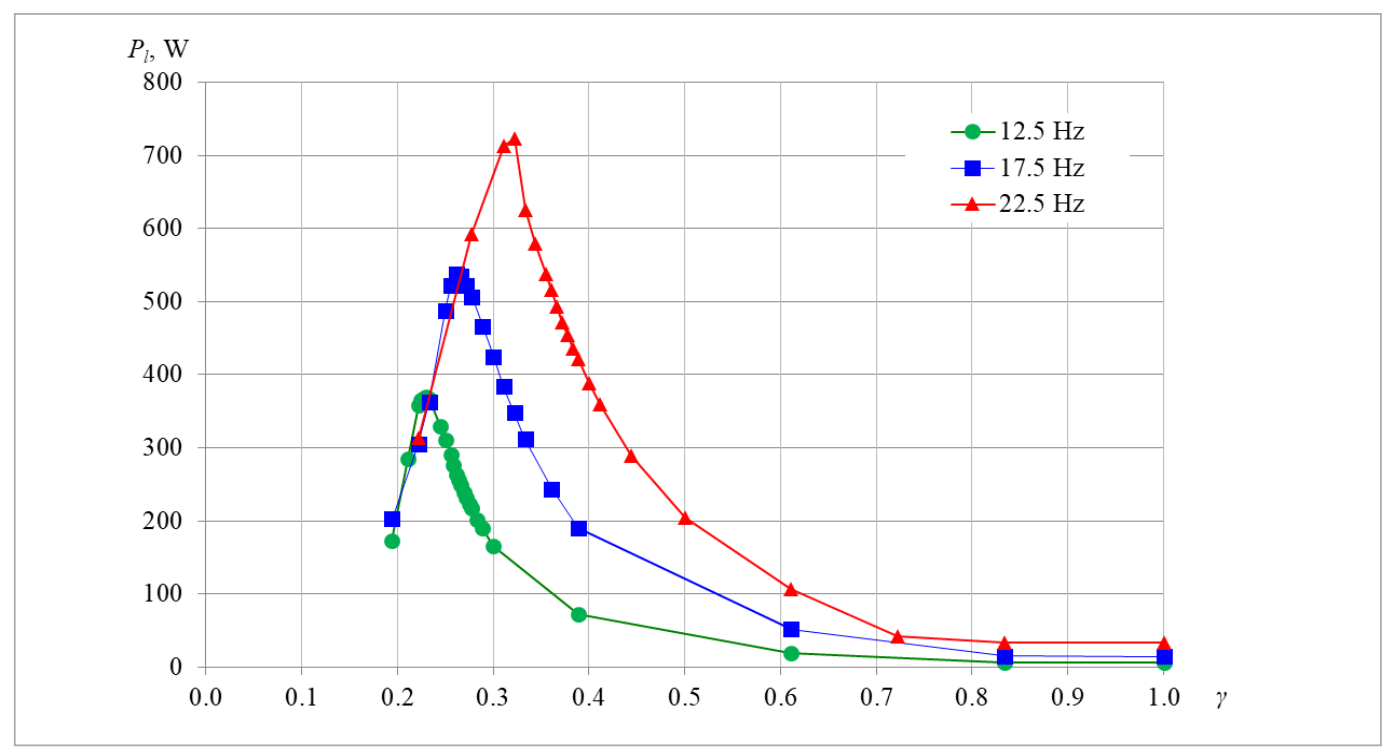

A few regimes of the hydraulic system work can be noticed for each value of $n_{\text {set }}$ not loaded system (approximately from $\gamma \approx 1$ to $\gamma \approx 0.8$, where: $n \rightarrow n_{\max }$, the torque of the shaft: $M \rightarrow M_{\min }$ ), loaded system (from $y \approx 0.8$ to $y \approx 0.22$, there: $n \rightarrow n_{\text {opt }}, M \rightarrow M_{\text {opt }}, P_{l} \rightarrow P_{\text {lmax }}$ ) and overloaded system (from $\gamma \approx 0.2$ to $\gamma \rightarrow 0$, there: $n \rightarrow 0, M \rightarrow M_{\max }, P_{l} \rightarrow 0$ ). The optimal working regime of the hydraulic system (the point of $P_{l}=P_{\text {lmax }}$, where $\gamma=\gamma_{\text {opt }}, n=n_{\text {opt }}, M=M_{\text {opt }}$ ) was in the zone of loaded system. 
The maximum amount of generated thermal energy was equal to $P_{l}=369.3$ at $\gamma_{\text {opt }}=0.231$ for $n_{\text {set }}=12.5$ $\mathrm{Hz}, P_{i}=537.9$ at $\gamma_{\text {opt }}=0.261$ for $n_{\text {set }}=17.5 \mathrm{~Hz}$ and $P_{l}=722.9$ at $\gamma_{\text {opt }}=0.322$ for $n_{\text {set }}=22.5 \mathrm{~Hz}$. Dependence of the amount of generated thermal energy $\left(P_{l}\right)$ on the rotation frequency of the pump $(n)$ is shown in Fig. 4. The optimal values of the rotation frequency of the shaft of the hydraulic pump were equal to $n_{\text {opt }}=10.3 \mathrm{~Hz}$ for $n_{\text {set }}=12.5 \mathrm{~Hz}, n_{\text {opt }}=14.5 \mathrm{~Hz}$ for $n_{\text {set }}=17.5 \mathrm{~Hz}$ and $n_{\text {opt }}=20.2 \mathrm{~Hz}$ for $n_{\text {set }}=22.5 \mathrm{~Hz}$.

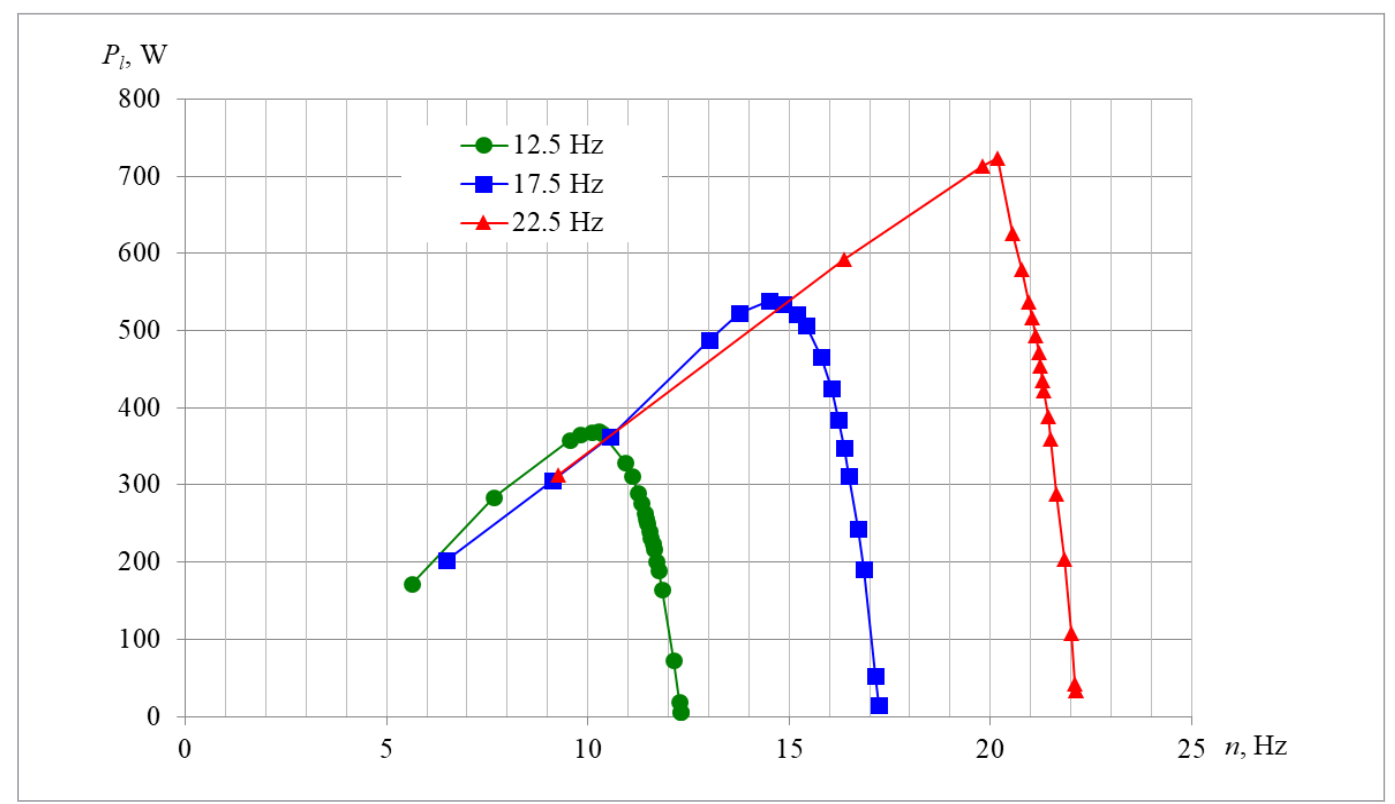

Fig. 4

Dependence of the amount of generated thermal energy on the rotation frequency of the pump at $\mathrm{T} \approx 20^{\circ} \mathrm{C}$

The influence of increase of oil temperature in the range from $20^{\circ} \mathrm{C}$ to $50^{\circ} \mathrm{C}$ on optimal parameters of the hydraulic system was investigated also. The dependence of the amount of generated thermal energy $\left(P_{l}\right)$ on the oil temperature $(T)$ for $n_{\text {set }}=12.5 \mathrm{~Hz}$ is shown in Fig. 5.

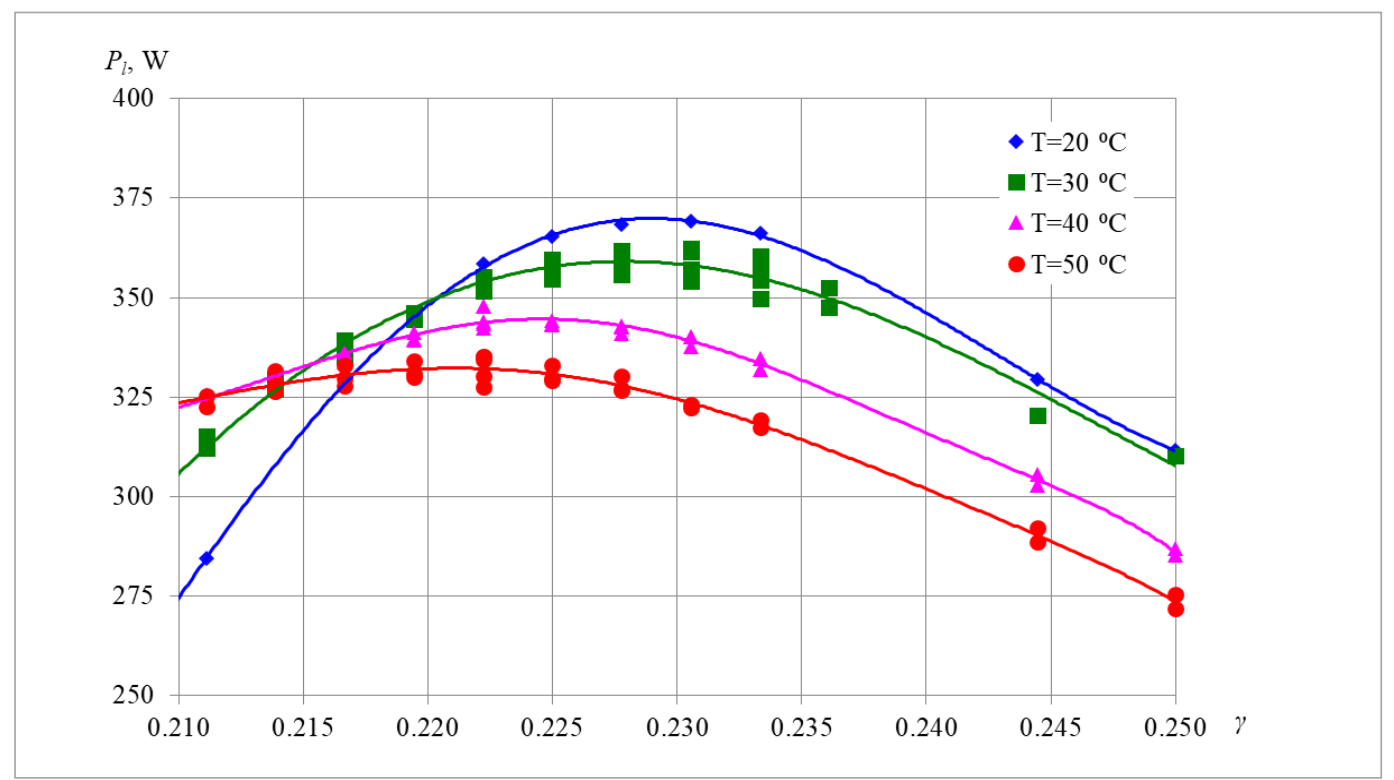

Fig. 5

Dependence of the amount of generated thermal energy on the oil temperature for $n_{\text {set }}=12.5 \mathrm{~Hz}$ 
With increase of oil temperature from $T \approx 20^{\circ} \mathrm{C}$ to $T \approx 50^{\circ} \mathrm{C}$ the maximum amount of generated thermal energy decreased from $P_{l \max }=369.3 \mathrm{~W}$ to $P_{l \max }=335.1 \mathrm{~W}\left(\Delta P_{l} / P_{l \max }=9.3 \%\right)$, the opening degree of the loading valve was changed from $\gamma_{\text {opt }}=0.231$ to $\gamma_{\text {opt }}=0.222$ and rotation frequency of pump changed from $n_{\text {opt }}=10.3 \mathrm{~Hz}$ to $n_{\text {opt }}=10.0 \mathrm{~Hz}$.

The dependences of the amount of generated thermal energy $\left(P_{l}\right)$ on the oil temperature $(T)$ for $n_{\text {set }}=17.5$ and $22.5 \mathrm{~Hz}$ are shown in Fig. 6 and Fig. 7. With increase of $T$ from $T \approx 20{ }^{\circ} \mathrm{C}$ to $T \approx 50{ }^{\circ} \mathrm{C}$ the $P_{l \max }$ decreased from $P_{l \max }=537.9 \mathrm{~W}$ to $P_{l \max }=524.6 \mathrm{~W}\left(\Delta P_{l} / P_{l \max }=2.5 \%\right), \gamma_{\text {opt }}$ was changed from $\gamma_{\text {opt }}=0.261$ to $\gamma_{\text {opt }}=0.256$ and $n_{\text {opt }}$ changed from $n_{\text {opt }}=14.5 \mathrm{~Hz}$ to $n_{\text {opt }}=14.2 \mathrm{~Hz}$ for $n_{\text {set }}=17.5 \mathrm{~Hz}$. Analogical, $P_{l \max }$ decreased from $P_{l \max }=722.9 \mathrm{~W}$ to $P_{l \max }=669.3 \mathrm{~W}\left(\Delta P_{l} / P_{l \max }=7.4 \%\right), \gamma_{\text {opt }}$ was changed from $\gamma_{\text {opt }}=0.322$ to $\gamma_{\text {opt }}=0.289$ and $n_{\text {opt }}$ changed from $n_{\text {opt }}=20.2 \mathrm{~Hz}$ to $n_{\text {opt }}=19.0 \mathrm{~Hz}$ for $n_{\text {set }}=22.5 \mathrm{~Hz}$.

Fig. 6

Dependence of the amount of generated thermal energy on the oil temperature for $n_{\text {set }}=17.5 \mathrm{~Hz}$

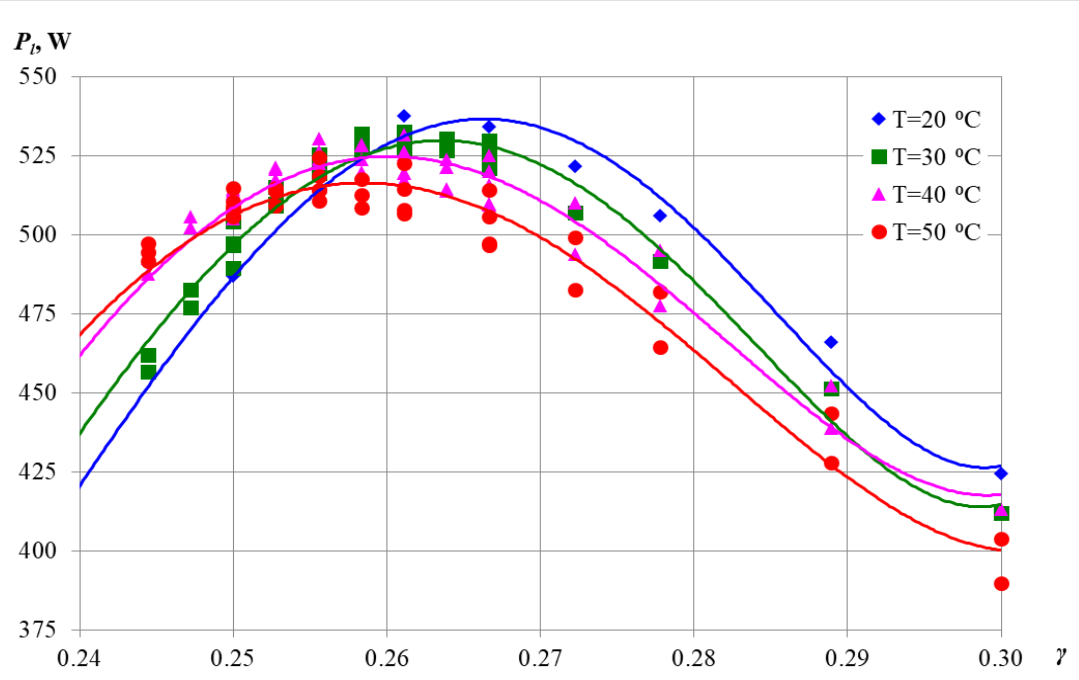

Fig. 7

Dependence of the amount of generated thermal energy on the oil temperature for $n_{\text {set }}=22.5 \mathrm{~Hz}$

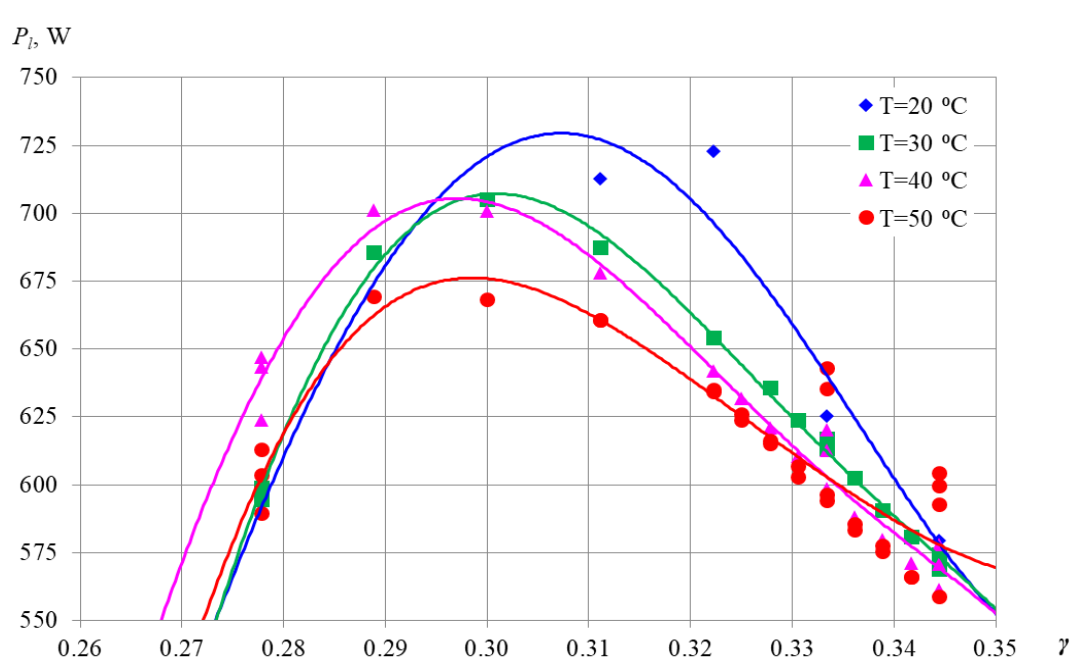


The data presented above is necessary for understanding and creating automatic regulation system of the hydraulic unit that uses wind for thermal energy generation. Some different schemes of control systems can be proposed (Ždankus et al. 2016). The sensor of the wind speed is the main for all schemes for control of the opening position of the loading valve of investigated hydraulic system. The feedback signal to controller can be generated in two cases: from the opening degree of the loading valve or from the pump shaft rotation frequency. The demand of an additional measurement of oil temperature is an object of discussion (Ždankus et al. 2016).

The losses of generated thermal energy would be $12 \mathrm{~W}$ or $3.6 \%$ for $n_{\text {set }}=12.5 \mathrm{~Hz}$ and $34.6 \mathrm{~W}$ or $5.2 \%$ for $n_{\text {set }}=22.5 \mathrm{~Hz}$ without the additional measurement of oil temperature for scheme with feedback from the sensor of opening degree of the loading valve. In other case, the losses of generated thermal energy would be $8.1 \mathrm{~W}$ or $2.4 \%$ for $n_{\text {set }}=12.5 \mathrm{~Hz}$ and $32.5 \mathrm{~W}$ or $4.9 \%$ for $n_{\text {set }}=22.5 \mathrm{~Hz}$ without the additional measurement of oil temperature for scheme with feedback from the sensor of pump shaft rotation frequency.

The experiments were carried out at additional different electromotor rotational speeds: $12.5,17.5$ and $22.5 \mathrm{~Hz}$. The relationship between the opening degree of the valve and the amount of generated thermal energy was determined. It was noticed that an optimal work regime of system was reached by changing the opening degree of load control valve from 0.1 to 0.33 . The maximum amount of generated thermal energy was equal to $P_{l}=369.3 \mathrm{~W}$ at $\gamma_{\text {opt }}=0.231$ and $n_{\text {opt }}=10.3 \mathrm{~Hz}$ for $n_{\text {set }}=12.5 \mathrm{~Hz}, P_{l}=537.9 \mathrm{~W}$ at $\gamma_{\text {opt }}=0.261$ and $n_{\text {opt }}=14.5 \mathrm{~Hz}$ for $n_{\text {set }}=17.5 \mathrm{~Hz}$ and $P_{l}=722.9 \mathrm{~W}$ at $\gamma_{\text {opt }}=0.322$ and $n_{\text {opt }}=20.2 \mathrm{~Hz}$ for $n_{\text {set }}=22.5 \mathrm{~Hz}$.

It was noticed that a change in the kinematic fluid viscosity influences on the amount of generated heat and the optimal value of the opening degree of the loading valve and rotation frequency of the pump. With increase of oil temperature from $T \approx 20{ }^{\circ} \mathrm{C}$ to $T \approx 50{ }^{\circ} \mathrm{C}$ the maximum amount of generated thermal energy decreased from $P_{l \max }=369.3 \mathrm{~W}$ to $P_{l \max }=335.1 \mathrm{~W}\left(\Delta P_{l} / P_{l \max }=9.3 \%\right)$ for $n_{\text {set }}=12.5 \mathrm{~Hz}$ and $P_{\text {lmax }}$ decreased from $P_{\text {lmax }}=722.9 \mathrm{~W}$ to $P_{\text {lmax }}=669.3 \mathrm{~W}\left(\Delta P_{l} / P_{l \max }=7.4 \%\right)$, for $n_{\text {set }}=22.5 \mathrm{~Hz}$. The same hydraulic system can generate more thermal power when it is working in lower temperatures, so it suggests combining wind power usage for building heating with the help of heat pumps that accept heat sources with relatively low temperatures.

Černeckiene J. Usage of the Wind Energy for Heating of the Energy-Efficient Buildings: Analysis of Possibilities. Journal of Sustainable Architecture and Civil Engineering, 2015, 10: 58-65. https://doi. org/10.5755/j01.sace.10.1.7479

Černeckienè J., Ždankus T. Vèjo energijos panaudojimo šilumos gamybai, taikant hidraulinę sistemą, tyrimas, Energetika, 2015, T61, 1: 32-43. https://doi. org/10.6001/energetika.v61i1.3094

Katinas V., Markevicius A., Perednis E., Savickas J. Sustainable energy development - Lithuania's way to energy supply security and energetics indepen- dence, Renew. Sustain. Energy Rev., 2014, 30: 420428. https://doi.org/10.1016/j.rser.2013.10.033

Robert J. K. V., Street L., Watters G. Z. Elementary Fluid Mechanics, John Wiley \& Sons, 1996.

Stigka E. K., Paravantis J. A., Mihalakakou G. K. Social acceptance of renewable energy sources: A review of contingent valuation applications, Renew. Sustain. Energy Rev., 2014, 32: 100-106. https://doi. org/10.1016/j.rser.2013.12.026

Yeaple F. Fluid power design handbook, CRC Press, 1995.

\section{Conclusions}

\section{References}


Ždankus T.; Černeckienè J.; Jurelionis A.; Vaičiūnas J. Experimental study of a small scale hydraulic system for mechanical wind energy conversion into heat. Sustainability. Basel: MDPI AG., 2016, vol. 8, iss. 7, Article 637: p. [1-18]. https://doi.org/10.3390/ su8070637

Žiedelis S. Hidraulinès ir pneumatinès sistemos, Kaunas, 2009.

\begin{tabular}{|c|c|c|c|c|c|}
\hline \multirow[t]{7}{*}{$\begin{array}{r}\text { About the } \\
\text { Authors }\end{array}$} & $\begin{array}{l}\text { TADAS } \\
\text { ZDANKUS }\end{array}$ & $\begin{array}{l}\text { JURGITA } \\
\text { CERNECKIENE }\end{array}$ & $\begin{array}{l}\text { LEONAS } \\
\text { GREIČIUS }\end{array}$ & $\begin{array}{l}\text { VIDAS } \\
\text { STANEVIČIUS }\end{array}$ & $\begin{array}{l}\text { NERIJUS } \\
\text { BUNIKIS }\end{array}$ \\
\hline & Professor & Lecturer & Master student & Master student & Master student \\
\hline & $\begin{array}{l}\text { Kaunas University } \\
\text { of Technology, } \\
\text { Faculty of Civil } \\
\text { Engineering and } \\
\text { Architecture }\end{array}$ & $\begin{array}{l}\text { Kaunas University } \\
\text { of Technology, } \\
\text { Faculty of Civil } \\
\text { Engineering and } \\
\text { Architecture }\end{array}$ & $\begin{array}{l}\text { Kaunas University } \\
\text { of Technology, } \\
\text { Faculty of Civil } \\
\text { Engineering and } \\
\text { Architecture }\end{array}$ & $\begin{array}{l}\text { Kaunas } \\
\text { University of } \\
\text { Technology, } \\
\text { Faculty of Civil } \\
\text { Engineering and }\end{array}$ & $\begin{array}{l}\text { Kaunas University } \\
\text { of Technology, } \\
\text { Faculty of Civil } \\
\text { Engineering and } \\
\text { Architecture }\end{array}$ \\
\hline & $\begin{array}{l}\text { Main research } \\
\text { area }\end{array}$ & Main research area & $\begin{array}{l}\text { Main research } \\
\text { area }\end{array}$ & $\begin{array}{l}\text { Architecture } \\
\text { Main research }\end{array}$ & $\begin{array}{l}\text { Main research } \\
\text { area }\end{array}$ \\
\hline & $\begin{array}{l}\text { Fluid mechanics, } \\
\text { wind energy } \\
\text { conversion, } \\
\text { thermal }\end{array}$ & $\begin{array}{l}\text { in buildings, HVAC } \\
\text { systems, renewable } \\
\text { energy }\end{array}$ & $\begin{array}{l}\text { Wind energy } \\
\text { conversion } \\
\text { Address }\end{array}$ & $\begin{array}{l}\text { area } \\
\text { Wind energy } \\
\text { conversion }\end{array}$ & $\begin{array}{l}\text { Wind energy } \\
\text { conversion } \\
\text { Address }\end{array}$ \\
\hline & storage & Address & Studentu st. 48, & Address & Studentu st. 48, \\
\hline & $\begin{array}{l}\text { Address } \\
\text { Studentu st. 48, } \\
\text { LT-51367 Kaunas, } \\
\text { Lithuania } \\
\text { E-mail: tadas. } \\
\text { zdankus@ktu.lt }\end{array}$ & $\begin{array}{l}\text { Studentu st. 48, } \\
\text { LT-51367 Kaunas, } \\
\text { Lithuania } \\
\text { Tel.+37061531533 } \\
\text { E-mail: jurgita. } \\
\text { cerneckiene@ktu.lt }\end{array}$ & $\begin{array}{l}\text { LT-51367 Kaunas, } \\
\text { Lithuania } \\
\text { E-mail: leonas. } \\
\text { greicius@ktu.edu }\end{array}$ & $\begin{array}{l}\text { Studentu st. } \\
\text { 48, LT-51367 } \\
\text { Kaunas, } \\
\text { Lithuania }\end{array}$ & $\begin{array}{l}\text { LT-51367 Kaunas, } \\
\text { Lithuania } \\
\text { E-mail: } \\
\text { nerijus.bunikis@ } \\
\text { ktu.edu }\end{array}$ \\
\hline
\end{tabular}

